Journal of Teacher Education for Sustainability, vol. 11, no. 2, pp. 3-13, 2009

\title{
THE IMPACT OF INITIAL FIELD EXPERIENCE ON PRE-SERVICE TEACHERS' ATTITUDE TOWARD INCLUSION
}

\author{
Peggy Gill, Ross Sherman and Cynthia Sherman \\ University of Texas at Tyler, USA
}

\begin{abstract}
In the United States, up to 50\% of new teachers leave the profession within 5 years (Smith o Ingersoll, 2004). This unacceptable level of sustainability of the profession is of concern to both teacher preparation institutions and the local education agencies. This paper looks at one factor that may impact the sustainability of current teacher preparation models: attitudes toward inclusion of students with disabilities in the mainstream classroom. Participants in the study were currently enrolled in 3 different phases of a teacher preparation programmes at a regional university in the United States. A survey was administered at the beginning and at the end of the semester. Results indicate that students become progressively more negative toward inclusion of students with disabilities in the general education classroom yet continue to support the social value of having all students in a general education setting. Results from the survey are presented and implications for practice are discussed.
\end{abstract}

Key words: inclusion; teacher preparation; attitudes; disabilities; pre-service.

\section{Introduction}

In the United States, up to $50 \%$ of new teachers leave the profession within 5 years (Smith, Ingersoll, 2004). This unacceptable level of sustainability of the profession is of concern to both teacher preparation institutions and the local education agencies. This paper looks at one factor that may impact the sustainability of current teacher preparation models: attitudes toward inclusion of students with disabilities in the mainstream classroom.

In the United States, the passage of Public Law 94-142 in 1975 and its reauthorization as the Individuals with Disabilities Education Act (IDEA) in 1997 and 2004 dramatically changed the way students with special needs are educated. This law requires that students with disabilities must receive instruction along with students without disabilities to the maximum extent appropriate. While IDEA does not mandate inclusion, it does require that the first placement considered for students with disabilities 
is the general education classroom with supplementary aids and services. Coupled with this move toward inclusion is the wave of increased accountability that demands that all children participate in a standards-based education (Lindsey, Roberts, \& CampbellJones, 2005). Research indicates that the teacher is the most important element that affects student learning in the classroom (Marzano, 2003). Even more importantly, Mcleskey, Waldron (2007) suggest that the attitudes and expectations of teachers directly affect the academic performance of children in the classroom.

The social model of disability theory and social learning theory suggest that the societal climate, including the environment, people and behaviours can have a significant impact on anyone within that context including teachers, students (with and without disabilities) and pre-service teachers. Further the social model of disability theory proposes a difference between impairment and disability. Impairment is "an attribute of the individual mind or body" and disability is "a relationship between a person with impairment and society" (Barnartt \& Altman, 2001, p. 17). A person with an impairment may have to engage in activities in ways that are different from most people, but society frequently sees this as an inability to engage in "normal" activities. Thus disability comes not only from impairment but also from reaction to the barriers that restrain engagement in activities. These barriers may be both physical and attitudinal and serve to constrain the lives of those with impairments.

\section{The problem and the purpose of the study}

Pre-service teachers are forming their attitudes and opinions toward students with disabilities. Informal surveys indicate that most pre-service teachers have had little if any experience with students with disabilities. Given the importance of attitude in successfully meeting the academic needs of these children, examining their developing attitudes as they prepare to step in the classroom provides valuable information to the teacher preparation programme as to whether additional or different experiences need to be provided. Do current teacher preparation programmes adequately address the needs of pre-service teachers as reflected in their attitudes toward children with disabilities? Is the current model of teacher preparation developing a sustainable teaching force?

The purpose of this study was to investigate the attitudes of pre-service teachers toward students with disabilities at three definite points in the training programme. Specifically, it seeks to find out:

1. Do pre-service teachers' attitudes change as they are exposed to classrooms in which students with and without disabilities work together?

2. Do pre-service teachers' attitudes change as they assume more teaching responsibilities in these classrooms?

\section{Context and method}

The Educator Certification Programme within the College of Education and Psychology is divided into three programme areas: grades EC-6, grades 4-8 and grades 8-12. The initial certification programme is a collaborative, field-based programme. The programme provides for the mediated induction of students into the teaching profession 
through field basing of professional education course work in a number of professional development school sites. This model emphasizes the importance of sustainability as a process of life-long professional development.

The EC -6 programme is divided into four Phases. Phase I classes are completed on campus and include a Survey of Exceptionality class and nine hours of observation in public schools. Phase II students spend one day a week in schools and teach a minimum of four lessons during the semester. During Phase III students take a two-semester credit hour class entitled, Educational Strategies for Individuals with Special Needs and are in the schools 10 hours a week and teach three lessons per week. Finally, Phase IV students are student teaching in schools.

This study used a survey administered to pre-service teachers in a regional university in the southwestern United States. The population of the study comprised all pre-service teachers in Phase II, Phase III and Phase IV, Pre-Service teaching in the School of Education in the 2008 fall semester. The survey was distributed by the researchers to all pre-service teachers (Phase II (47), Phase III (33) and Pre-Service Teachers (60)) in August during orientation meetings for the semester. The same survey was re-administered in December at the end of the semester. Survey data were analyzed using SPSS 15.0 for Windows. Data were examined to identify changes in attitudes over the semester. Data were aggregated at the group level.

\section{Findings}

Phase II students had the least changes in attitudes. However, they became more likely to believe that the needs of students with disabilities can best be served through special separate programmes or classrooms $(.17)$ and that it is difficult to maintain order in a general education classroom that contains students with disabilities (.12). They also were more likely to believe that placing students with disabilities in a general education setting would help them be more independent.

Table 1. Phase II attitudes toward students with disabilities

\begin{tabular}{lcccc}
\hline & \multicolumn{2}{c}{ August } & \multicolumn{2}{c}{ December } \\
\cline { 2 - 5 } & Agree & Disagree & Agree & Disagree \\
\hline $\begin{array}{l}\text { Students with disabilities need to be in special } \\
\text { classrooms. }\end{array}$ & $25 \%$ & $75 \%$ & $33 \%$ & $67 \%$ \\
\hline $\begin{array}{l}\text { Students with disabilities are more difficult to } \\
\text { teach than their non-disabled peers. }\end{array}$ & $45 \%$ & $55 \%$ & $36 \%$ & $64 \%$ \\
\hline $\begin{array}{l}\text { Mixing students with disabilities and students } \\
\text { without disabilities in one class will foster } \\
\text { understanding and acceptance of differences } \\
\text { among them. }\end{array}$ & $100 \%$ & & & \\
\hline $\begin{array}{l}\text { Parents of students with disabilities are a } \\
\text { greater problem for general education } \\
\text { classroom teachers. }\end{array}$ & $2 \%$ & $98 \%$ & $6 \%$ & $94 \%$ \\
\hline
\end{tabular}


Sequel to Table 1.

Inclusion of students with disabilities will require the retraining of the general education $\quad 77 \% \quad 23 \% \quad 76 \% \quad 24 \%$ staff.

The needs of students with disabilities can best be served through special separate programme $\quad 39 \% \quad 61 \% \quad 49 \% \quad 51 \%$ or classrooms.

The extra attention students with disabilities require will take away from their non-disabled $\quad 33 \% \quad 67 \% \quad 40 \% \quad 60 \%$ peers.

It is difficult to maintain order in a general education classroom that contains students $\quad 12 \% \quad 88 \% \quad 24 \% \quad 76 \%$ with disabilities.

The challenge of being in a general education classroom will promote the growth and $\quad 80 \% \quad 20 \% \quad 91 \% \quad 9 \%$ development of students with disabilities.

Providing instruction in a self-contained or resource classroom has a negative effect on the development of students with disabilities.

The interaction between students without disabilities and students with disabilities in the general education setting may be harmful to students without disabilities.

\begin{tabular}{|c|c|c|c|c|}
\hline $\begin{array}{l}\text { Placing students with disabilities in a general } \\
\text { education setting will help them be more } \\
\text { independent. }\end{array}$ & $80 \%$ & $20 \%$ & $91 \%$ & $9 \%$ \\
\hline $\begin{array}{l}\text { Students with disabilities are more of a burden } \\
\text { to teach than their non-disabled peers. }\end{array}$ & $11 \%$ & $89 \%$ & $19 \%$ & $81 \%$ \\
\hline $\begin{array}{l}\text { Students with disabilities should not be in the } \\
\text { same class as students without disabilities. }\end{array}$ & $14 \%$ & $86 \%$ & $13 \%$ & $87 \%$ \\
\hline $\begin{array}{l}\text { Students with disabilities interact best with } \\
\text { other students with disabilities. }\end{array}$ & $11 \%$ & $89 \%$ & $16 \%$ & $84 \%$ \\
\hline $\begin{array}{l}\text { Students with disabilities cannot learn the same } \\
\text { things (on the same level) as their non- } \\
\text { disabled peers. }\end{array}$ & $25 \%$ & $75 \%$ & $22 \%$ & $78 \%$ \\
\hline $\begin{array}{l}\text { Students with disabilities will develop skills } \\
\text { more rapidly in a special education classroom } \\
\text { than in a general education classroom. }\end{array}$ & $30 \%$ & $70 \%$ & $28 \%$ & $72 \%$ \\
\hline
\end{tabular}

Phase III students' attitudinal changes were consistently less favorable toward the student with disabilities. Phase III participants were significantly more likely to believe that parents of students with disabilities are a greater problem for general education teachers (.01). They were also more likely to believe the interaction between students without disabilities and students with disabilities in the general education setting may be harmful (.11). They were slightly more likely to believe students with disabilities need to be in special classroom (.13). 
Table 2. Phase III participants' attitudes toward students with disabilities

\begin{tabular}{|c|c|c|c|c|}
\hline & \multicolumn{2}{|c|}{ August } & \multicolumn{2}{|c|}{ December } \\
\hline & Agree & Disagree & Agree & Disagree \\
\hline $\begin{array}{l}\text { Students with disabilities need to be in special } \\
\text { classrooms. }\end{array}$ & $31 \%$ & $69 \%$ & $39 \%$ & $61 \%$ \\
\hline $\begin{array}{l}\text { Students with disabilities are more difficult to } \\
\text { teach than their non-disabled peers. }\end{array}$ & $35 \%$ & $65 \%$ & $42 \%$ & $58 \%$ \\
\hline $\begin{array}{l}\text { Mixing students with disabilities and students } \\
\text { without disabilities in one class will foster } \\
\text { understanding and acceptance of differences } \\
\text { among them. }\end{array}$ & $97 \%$ & $3 \%$ & $90 \%$ & $10 \%$ \\
\hline $\begin{array}{l}\text { Parents of students with disabilities are a } \\
\text { greater problem for general education } \\
\text { classroom teachers. }\end{array}$ & $7 \%$ & $93 \%$ & $5 \%$ & $95 \%$ \\
\hline $\begin{array}{l}\text { Inclusion of students with disabilities will } \\
\text { require the retraining of the general } \\
\text { education staff. }\end{array}$ & $59 \%$ & $41 \%$ & $79 \%$ & $21 \%$ \\
\hline $\begin{array}{l}\text { The needs of students with disabilities can best } \\
\text { be served through special separate programme } \\
\text { or classrooms. }\end{array}$ & $48 \%$ & $52 \%$ & $48 \%$ & $52 \%$ \\
\hline $\begin{array}{l}\text { The extra attention students with disabilities } \\
\text { require will take away from their non-disabled } \\
\text { peers. }\end{array}$ & $35 \%$ & $65 \%$ & $36 \%$ & $64 \%$ \\
\hline $\begin{array}{l}\text { It is difficult to maintain order in a general } \\
\text { education classroom that contains students } \\
\text { with disabilities. }\end{array}$ & $10 \%$ & $90 \%$ & $16 \%$ & $84 \%$ \\
\hline $\begin{array}{l}\text { The challenge of being in a general education } \\
\text { classroom will promote the growth and } \\
\text { development of students with disabilities. }\end{array}$ & $100 \%$ & & $81 \%$ & $19 \%$ \\
\hline $\begin{array}{l}\text { Providing instruction in a self-contained or } \\
\text { resource classroom has a negative effect on } \\
\text { the development of students with disabilities. }\end{array}$ & $40 \%$ & $60 \%$ & $29 \%$ & $71 \%$ \\
\hline $\begin{array}{l}\text { The interaction between students without } \\
\text { disabilities and students with disabilities in } \\
\text { the general education setting may be harmful } \\
\text { to students without disabilities. }\end{array}$ & $7 \%$ & $93 \%$ & $11 \%$ & $89 \%$ \\
\hline $\begin{array}{l}\text { Placing students with disabilities in a general } \\
\text { education setting will help them be more } \\
\text { independent. }\end{array}$ & $93 \%$ & $7 \%$ & $85 \%$ & $15 \%$ \\
\hline $\begin{array}{l}\text { Students with disabilities are more of a burden } \\
\text { to teach than their non-disabled peers. }\end{array}$ & $14 \%$ & $86 \%$ & $6 \%$ & $94 \%$ \\
\hline $\begin{array}{l}\text { Students with disabilities should not be in the } \\
\text { same class as students without disabilities. }\end{array}$ & & $100 \%$ & $16 \%$ & $84 \%$ \\
\hline
\end{tabular}


Sequel to Table 2.

Students with disabilities interact best with $\quad \begin{array}{llll}7 \% & 93 \% & 17 \% & 83 \%\end{array}$ other students with disabilities.

Students with disabilities cannot learn the same things (on the same level) as their nondisabled peers.

Students with disabilities will develop skills more rapidly in a special education classroom $\quad 31 \% \quad 69 \% \quad 35 \% \quad 65 \%$ than in a general education classroom.

Analysis of the data indicates that pre-service teacher participants (phase IV) have the most significant changes in attitudes toward students with disabilities. After the pre-service teaching experience, participants were significantly more likely to believe students with disabilities should be in a special classroom (.07), that students with disabilities take time away from their peers (.01), that it is difficult to maintain order in a classroom that has students with disabilities (.05), that students with disabilities should not be in the general education classroom (.02), that students with disabilities cannot learn the same things as their non-disabled peers (.10), and that students with disabilities will develop skills more rapidly in a special education classroom (.01). They are significantly less likely to believe mixing students in the general population will promote growth and understanding (.05).

Table 3. Pre-service teacher participants' attitude toward students with disabilities

\begin{tabular}{lcccc}
\hline & \multicolumn{2}{c}{ August } & \multicolumn{2}{c}{ December } \\
\cline { 2 - 5 } & Agree & Disagree & Agree & Disagree \\
\hline $\begin{array}{l}\text { Students with disabilities need to be in special } \\
\text { classrooms. }\end{array}$ & $26 \%$ & $74 \%$ & $54 \%$ & $46 \%$ \\
\hline $\begin{array}{l}\text { Students with disabilities are more difficult to } \\
\text { teach than their non-disabled peers. }\end{array}$ & $48 \%$ & $52 \%$ & $48 \%$ & $52 \%$ \\
\hline $\begin{array}{l}\text { Mixing students with disabilities and students } \\
\text { without disabilities in one class will foster }\end{array}$ & $93 \%$ & $7 \%$ & $84 \%$ & $16 \%$ \\
$\begin{array}{l}\text { understanding and acceptance of differences } \\
\text { among them. }\end{array}$ & & & & \\
\hline $\begin{array}{l}\text { Parents of students with disabilities are a } \\
\text { greater problem for general education } \\
\text { classroom teachers. }\end{array}$ & $7 \%$ & $93 \%$ & $11 \%$ & $89 \%$ \\
\hline $\begin{array}{l}\text { Inclusion of students with disabilities will } \\
\text { require the retraining of the general } \\
\text { education staff. }\end{array}$ & $44 \%$ & $56 \%$ & $72 \%$ & $28 \%$ \\
$\begin{array}{l}\text { The needs of students with disabilities can } \\
\text { best be served through special separate } \\
\text { programme or classrooms. }\end{array}$ & $41 \%$ & $59 \%$ & $48 \%$ & $52 \%$ \\
\hline
\end{tabular}


Sequel to Table 3.

The extra attention students with disabilities

require will take away from their non- $\quad 41 \% \quad 59 \% \quad 54 \% \quad 46 \%$
disabled peers.

It is difficult to maintain order in a general education classroom that contains students $\quad 10 \% \quad 90 \% \quad 22 \% \quad 78 \%$ with disabilities.

The challenge of being in a general education classroom will promote the growth and development of students with disabilities.

Providing instruction in a self-contained or resource classroom has a negative effect on the development of students with disabilities.

The interaction between students without disabilities and students with disabilities in the general education setting may be harmful to students without disabilities.

Placing students with disabilities in a general education setting will help them be more independent.

Students with disabilities are more of a burden to teach than their non-disabled peers.

Students with disabilities should not be in $88 \% \quad 12 \% \quad 77 \% \quad 23 \%$ the same class as students without disabilities.

\begin{tabular}{lllll}
\hline Students with disabilities interact best with & $18 \%$ & $82 \%$ & $21 \%$ & $77 \%$
\end{tabular}
other students with disabilities.

Students with disabilities cannot learn the same things (on the same level) as their non-disabled peers.

Students with disabilities will develop skills more rapidly in a special education $79 \% \quad 21 \% \quad 72 \% \quad 28 \%$ $28 \% \quad 72 \% \quad 20 \% \quad 80 \%$ classroom than in a general education classroom.

Overall, the change in attitude experienced by these future teachers seems to be a less favorable attitude toward students with disabilities. The pre-service teacher experience in the classroom is most likely to result in a negative change in attitude. There was, however, strong endorsement of the social values of students with and without disabilities interacting in the general education setting. 
Table 4. Comparison of pre-service teacher attitudes toward students with disabilities: december

\begin{tabular}{|c|c|c|c|c|c|c|}
\hline & \multicolumn{2}{|c|}{ Phase II } & \multicolumn{2}{|c|}{ Phase III } & \multicolumn{2}{|c|}{ Student Teaching } \\
\hline & Agree & Disagree & Agree & Disagree & Agree & Disagree \\
\hline $\begin{array}{l}\text { Students with disabilities need } \\
\text { to be in special classrooms. }\end{array}$ & $33 \%$ & $67 \%$ & $39 \%$ & $61 \%$ & $54 \%$ & $46 \%$ \\
\hline $\begin{array}{l}\text { Students with disabilities are } \\
\text { more difficult to teach than } \\
\text { their non-disabled peers. }\end{array}$ & $36 \%$ & $64 \%$ & $42 \%$ & $58 \%$ & $48 \%$ & $52 \%$ \\
\hline $\begin{array}{l}\text { Mixing students with disabi- } \\
\text { lities and students without } \\
\text { disabilities in one class will } \\
\text { foster understanding and } \\
\text { acceptance of differences } \\
\text { among them. }\end{array}$ & $100 \%$ & & $90 \%$ & $10 \%$ & $84 \%$ & $16 \%$ \\
\hline $\begin{array}{l}\text { Parents of students with dis- } \\
\text { abilities are a greater problem } \\
\text { for general education class- } \\
\text { room teachers. }\end{array}$ & $6 \%$ & $94 \%$ & $5 \%$ & $95 \%$ & $11 \%$ & $89 \%$ \\
\hline $\begin{array}{l}\text { Inclusion of students with } \\
\text { disabilities will require the } \\
\text { retraining of the general } \\
\text { education staff. }\end{array}$ & $76 \%$ & $24 \%$ & $79 \%$ & $21 \%$ & $72 \%$ & $28 \%$ \\
\hline $\begin{array}{l}\text { The needs of students with } \\
\text { disabilities can best be served } \\
\text { through special separate } \\
\text { programme or classrooms. }\end{array}$ & $49 \%$ & $51 \%$ & $48 \%$ & $52 \%$ & $48 \%$ & $52 \%$ \\
\hline $\begin{array}{l}\text { The extra attention students } \\
\text { with disabilities require will } \\
\text { take away from their non- } \\
\text { disabled peers. }\end{array}$ & $40 \%$ & $60 \%$ & $36 \%$ & $64 \%$ & $54 \%$ & $46 \%$ \\
\hline $\begin{array}{l}\text { It is difficult to maintain order } \\
\text { in a general education class- } \\
\text { room that contains students } \\
\text { with disabilities. }\end{array}$ & $24 \%$ & $76 \%$ & $16 \%$ & $84 \%$ & $22 \%$ & $78 \%$ \\
\hline $\begin{array}{l}\text { The challenge of being in a } \\
\text { general education classroom } \\
\text { will promote the growth and } \\
\text { development of students with } \\
\text { disabilities. }\end{array}$ & $91 \%$ & $9 \%$ & $81 \%$ & $19 \%$ & $77 \%$ & $23 \%$ \\
\hline $\begin{array}{l}\text { Providing instruction in a self- } \\
\text { contained or resource class- } \\
\text { room has a negative effect on } \\
\text { the development of students } \\
\text { with disabilities. }\end{array}$ & $28 \%$ & $72 \%$ & $29 \%$ & $71 \%$ & $20 \%$ & $80 \%$ \\
\hline
\end{tabular}


Sequel to Table 4.

The interaction between students without disabilities and students with disabilities in the general education setting may be harmful to students without disabilities.

Placing students with disabilities in a general education setting will help them be more independent.

Students with disabilities are more of a burden to teach $19 \% \quad 81 \% \quad 6 \% \quad 94 \% \quad 14 \% \quad 86 \%$ than their non-disabled peers.

Students with disabilities should not be in the same class as students without disabilities.

Students with disabilities interact best with other students with disabilities.

$\begin{array}{llllll}6 \% & 94 \% & 11 \% & 89 \% & 7 \% & 73 \%\end{array}$

Students with disabilities cannot learn the same things (on the same level) as their non-disabled peers.

Students with disabilities will develop skills more rapidly in a special education classroom than in a general education $91 \% \quad 9 \% \quad 85 \% \quad 15 \% \quad 72 \% \quad 28 \%$ classroom.

\section{Implications for practice}

The research has implications for development of a sustainable model for preparation of pre-service teachers. Most teacher preparation programmes in the United States utilize The Interstate New Teacher Assessment and Support Consortium's Model Standards for Beginning Teacher Licensing, Assessment and Development: A Resource for State Dialogue (1992) referred to as the INTASC Standards as the guide to identify the knowledge, dispositions and performances that new teachers should possess as a result of their educational preparation programme.

The INTASC Standards (2001) state that “...all teachers are responsible for providing an appropriate education to students with disabilities" and "all teachers, both general educators and special educators, must have knowledge and skills related to their subject matter discipline and the principles of effective teaching and learning as well as specific knowledge and skills drawn from the field of special education" (p. 1). 
The question is how to operationalize these premises in a teacher education programme so pre-service teacher's values and beliefs are consonant with these principles as a result of their teacher education preparation. Traditionally most institutions provide course work in special education with an assumption that knowledge about the field of special education will impact the pre-service teacher's values and beliefs. In addition, it is an accepted practice that students should be immersed in public schools throughout their teacher preparation so they experience working with students throughout the various phases of their preparation as a teacher. It is assumed that formal training and applied experiences will positively impact the teacher's values and beliefs about teaching and students. Although the teachers in this study received two courses in special education and had extensive field experiences their beliefs and values concerning students with disabilities actually deteriorated during their programme.

One intervening variable that could affect pre-service teacher's beliefs and values is their interactions with the teachers in the field. If their mentor teachers possess negative feelings toward the inclusion of students with disabilities in their class this could influence the pre-service teacher's values and beliefs.

What could teacher preparation programmes do to develop a sustainable model that will increase the likelihood that a pre-service teacher will develop positive values and beliefs about working with children with disabilities?

A series of recommendations are presented including:

1. University faculty should model a positive perception of students with disabilities in their classes.

2. All teacher education courses should address working with students with disabilities as appropriate.

3. Pre-service teachers should have the opportunity to watch teachers utilize successful practices with students with disabilities.

4. University faculty should engage pre-service teachers in a dialogue about their experiences working with students with disabilities throughout their field experiences.

5. Pre-service teachers should have the opportunity to reflect on their experiences in working with students with disabilities perhaps through journaling experiences.

This list is not exhaustive and there are other strategies that can complement the aforementioned to create a comprehensive programme that will foster positive values and beliefs about working with students with disabilities.

A second major consideration in developing a sustainable model is the field placement of the pre-service teachers. University faculty should make every effort to ensure that pre-service teachers are placed in classrooms in which teachers display a positive attitude toward students with disabilities. Each preparation programme should examine its selection process to choose mentor teachers. How is the issue of special education addressed in this process? Is there a history of success with students with special instructional needs in the mentor's classroom? Is there a collaborative culture on the campus that suggest special educators and regular educators work together to meet the needs of all students. Are there opportunities for the university supervisors to positively impact the climate of the school? 


\section{Conclusion}

With the goal of developing a sustainable model of teacher preparation, programmes are challenged to develop teachers who can work successfully with students with disabilities. This is both a legal requirement and a moral imperative. However, this study suggests that many pre-service teachers develop negative attitudes towards students with disabilities during their pre-service preparation programmes. Current classroom curriculum, field placements, and the selection of mentor teachers must be carefully reexamined to identify how to better prepare new teachers to handle the reality of today's classroom expectations. Teachers leaving the field frequently refer to lack of support and the challenges of classroom management as reasons for their departure. If new teachers enter the field with negative attitudes toward students identified as having learning disabilities, support will be crucial to their success. From the findings in this study, this support must begin in the field experiences through strong mentoring programmes that address successful teaching strategies while developing relationships that encourage reflective teaching approaches. With a strong foundation in teaching and a mediated induction period that emphasizes success for all students, a sustainable teaching force is possible.

This study looked at overall attitudes of pre-service teachers. Additional studies need to examine the specific variables that may be impacting these teachers in training. However, even without more knowledge about the specific variables, pre-service programmes and university faculty must be cognizant of how they can address this issue and foster positive beliefs and values about providing appropriate education for all.

\section{References:}

Barnartt, S., \& Altman, B. (2001). Exploring theories and expanding methodologies: Where we are and where we need to go. Kidlington, U.K.: Elsevier Science.

Interstate New Teacher Assessment and Support Consortium. (2001). Model standards for licensing general and special education teachers of students with disabilities: A resource for state dialogue. Washington, DC: Council of Chief State School Officers.

Interstate New Teacher Assessment and Support Consortium. (1992). Model standards for beginning teacher licensing, assessment and development: A resource for state dialogue. Washington, DC: Council of Chief State School Officers.

Lindsey, R. B., Roberts, L. M., \& Campbell-Jones, F. (2005). The culturally proficient school: An implementation guide for school leaders. Thousand Oaks, CA: Corwin Press.

Marzano, R. (2003). What works in schools: Translating research into action? Alexandria, VA: Association for Supervision and Curriculum Development.

McLeskey, J., \& Waldron, N. (2007). Making differences ordinary in inclusive classrooms. Intervention in School and Clinic, 42(3), 162-168.

Smith, T. M., \& Ingersoll, R. M. (2004). What are the effects of induction and mentoring on beginning teacher turnover? American Educational Research Journal, 41(3), 681-714.

\section{Correspondence:}

Peggy Gill, Ed.D., Professor, Department of Educational Leadership, University of Texas at Tyler, 3900 University Blvd., Tyler, TX 75799. Email: pgill@uttyler.edu 